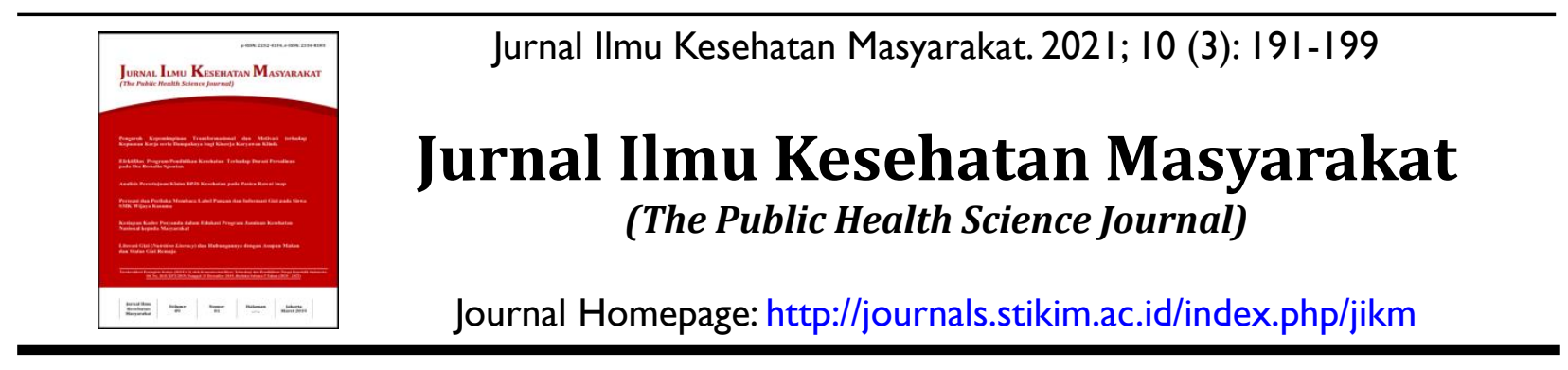

\title{
Pengendalian Demam Berdarah Dengue (DBD) Berbasis Masyarakat di Indonesia: Systematic Review
}

\author{
Wahyu Widyantoro ${ }^{1}$, Nurjazuli ${ }^{2}$, Yusniar Hanani Darundiati ${ }^{3}$ \\ ${ }^{1-3}$ Magister Kesehatan Lingkungan, Fakultas Kesehatan Masyarakat Universitas Diponegoro, Semarang \\ E-mail: kangbeyes@gmail.com ${ }^{1}$, nurjazuli@lecturer.undip.ac.id ${ }^{2}$, darundiatiyh@lecturer.undip.ac.id ${ }^{3}$
}

\begin{abstract}
Abstrak
Demam berdarah dengue (DBD) masih menjadi maslah kesehatan di Indonesia. Berbagai program telah dilaksanakan oleh pemerintah untuk menanggulangi DBD. Pelibatan masyarakat dalam pengendalian menjadi penting dalam upaya pengendalian DBD. Kajian sistematis ini bertujuan untuk mengetahui pelibatan komunitas dalam intervensi pengendalain DBD di Indonesia. Metode dalam penelitian ini adalah systematic review dengan menggunakan metode PRISMA. Kami melakukan pencarian literatur empat data base elektronik : Google Scholar, PubMed, Web of Science, Scopus dengan data open access dari tahun 2015 hingga 2020. Artikel dipilih berdasarkan kriteria inklusi community dengue control, engangment dengue control, sosial capital dengue control dan didapatkan 5 artikel yang sesuai untuk dikaji. Penelitian ini menggunakan metode studi pustaka dengan menggunakan data penelitian dengan topik yang sama sebagai data sekunder Pelibatan komunitas menjadi bagian keberhasilan dalam pengendalian DBD di Indonesia.hasil intervensi meliputi pengetahuan, sikap dan praktik di komunitas; partisipasi masyarakat; modal social dan pemberdayaan masyrakat mampu menurunkan parameter terhadap kejadian maupun kasus DBD. Keberhasilan pelibatan komunitas dalam pengendalian DBD di Indonesia perlu adanya program keberlanjutan dan kesinambungan.
\end{abstract}

Kata Kunci: Demam berdarah, pemberdayaan masyarakat, pengendalian DBD.

\begin{abstract}
Dengue fever is still a health problem in Indonesia. Various programs have been implemented by the government to tackle dengue fever. Community involvement in controlling becomes important in efforts to control DHF.This systematic study aims to determine community involvement in DHF control interventions in Indonesia. The method in this research is systematic review using the PRISMA method. We conducted a literature search on four electronic databases: Google Scholar, PubMed, Web of Science, Scopus with open access data from 2015 to 2020. Articles were selected based on the inclusion criteria of community dengue control, engagement dengue control, social capital dengue control and found 5 articles that are suitable for review. This research uses literature study method using research data with the same topic as secondary data. Community involvement is part of the success in controlling dengue fever in Indonesia. The results of the intervention include knowledge, attitudes and practices in the community; society participation; Social capital and community empowerment can reduce the parameters for the incidence and cases of DHF. The success of community involvement in DHF control in Indonesia requires a program of sustainability and sustainability.
\end{abstract}

Keywords: Dengue, Community empowerment, engangment dengue control. 


\section{Pendahuluan}

Demam berdarah dengue (DBD) merupakan penyakit terbesar yang disebabkan oleh arbovirus. ${ }^{1}$ Virus dengue ini ditularkan oleh nyamuk betina terutama dari spesies Aedes aegypti dan pada tingkat yang lebih rendah oleh Aedes albopictus. ${ }^{2}$ Di dunia diperkirakan terdapat 390 juta kasus DBD, dimana 96 juta diantaranya tampak nyata tingkat keparahan klinis atau sub-klinis. ${ }^{3,4}$ Demam berdarah telah menyebar di 128 negara dan diperkirakan 3, 9 miliar orang beresiko terinfeksi. ${ }^{5}$

Indonesia merupakan salah satu negara endemik DBD. Incidence Rate (IR) DBD di Indonesia, mengalami peningkatan lebih dari dua kali lipat pada tahun 2019 (51,53/100.000) dibandingkan tahun 2018 (24,75/100.000). Meskipun Case fatality rate (CFR) menunjukkan sedikit penurunan dari $0,71 \%$ pada tahun 2018 menjadi $0,67 \%$ pada tahun 2019. Terdapat 10 provinsi dengan dengan CFR $>1 \%$. Namun jumlah Kabupaten/Kota terjangkit DBD di Indonesia meningkat menjadi 481 atau 93,58 \% dari seluruh kabupaten/kota yang ada di Indonesia. ${ }^{6}$

Upaya pemberantasan DBD dilakukan antara lain melalui kegiatan pencegahan, penemuan, pelaporan penderita, pengamatan penyakit dan penyelidikan epidemiologi dan penyuluhan kepada masyarakat. ${ }^{7,8}$ Pemerintah telah melakukan berbagai strategi, pendekatan dan program untuk penanggulangan DBD, salah satu program pencegahan penyakit DBD telah dilakukan antara lain dengan memutus rantai penularan nyamuk dengan cara kegiatan Pemberantasan Sarang Nyamuk (PSN) melalui gerakan $3 \mathrm{M}$ (menguras, menutup dan mengubur). PSN merupakan cara pemberantasan yang lebih aman, murah dan sederhana sehingga pada tahun 1992 pemerintah mengeluarkan kebijakan dalam pengendalian vektor DBD lebih menitikberatkan pada program PSN DBD. ${ }^{9}$

Program berbasis masyarakat yang menggunakan berbagai intervensi sebagai strategi utama untuk untuk mengontrol atau mencegah penularan virus dengue. ${ }^{10}$ Namun, metode intervensi dengan pelibatan masyarakat tidak mudah dilakukan, karena lebih banyak membutuhkan partisipasi masyarakat secara aktif dan keberlanjutan. Penelitian sebelumnya menunjukan berbagai pendekatan pengendalian vektor yang efektif melalui pendekatan berbasis masyarakat. ${ }^{10}$ Studi ini bertujuan untuk membahas kompleksitas kemunculan demam berdarah, untuk mengidentifikasi strategi pengendalian yang berdasarkan keterlibatan masyarakat di Indonesia.

\section{Metoda}

Review ini mengikuti pedoman systematic review sebagaimana tercantum dalam pernyataan PRISMA namun tidak mengunakan meta analisis untuk merangkum hasil penelitian-penelitian sebelumnya. $^{11}$ penelitian ini dilakukan antara bulan November dan Desember 2020. Pencarian literatur menggunakan empat data base elektronik yaitu Google Scholar, PubMed, Web of Science dan Scopus. Pencarian mencakup semua literatur yang diterbitkan antara Januari 2015 dan Desember 2020. Pencarian secara independen oleh tiga peneliti, menggunakan reference manager Mendeley untuk semua kutipan dokumen. Artikel yang temukan sama pada kedua database dieliminasi. Kemudian judul dan abstrak disaring. Kemudian naskah dari artikel yang tersisa disaring bersama-sama untuk dimasukan dalam review.

Pencarian artikel mengunakan kata kunci community dengue control, engangment dengue control, sosial capital dengue control. Artikel yang tepilih dari proses penyaringan dianalisis oleh penulis untuk ekstrksi data, dan temuan diskusi dengan grup. Kriteria inklusi yang digunakan untuk menyaring artikel yaitu teks lengkap artikel yang berkaitan pengendalian DBD dengan pendekatan komunitas di Indonesia, studi kasus penelitian berada di Indonesia. Semua data disaring dan dikumpulkan secara manual. Alur untuk menetukan artikel yang dipilih sebagai berikut dalam Gambar 1 . 


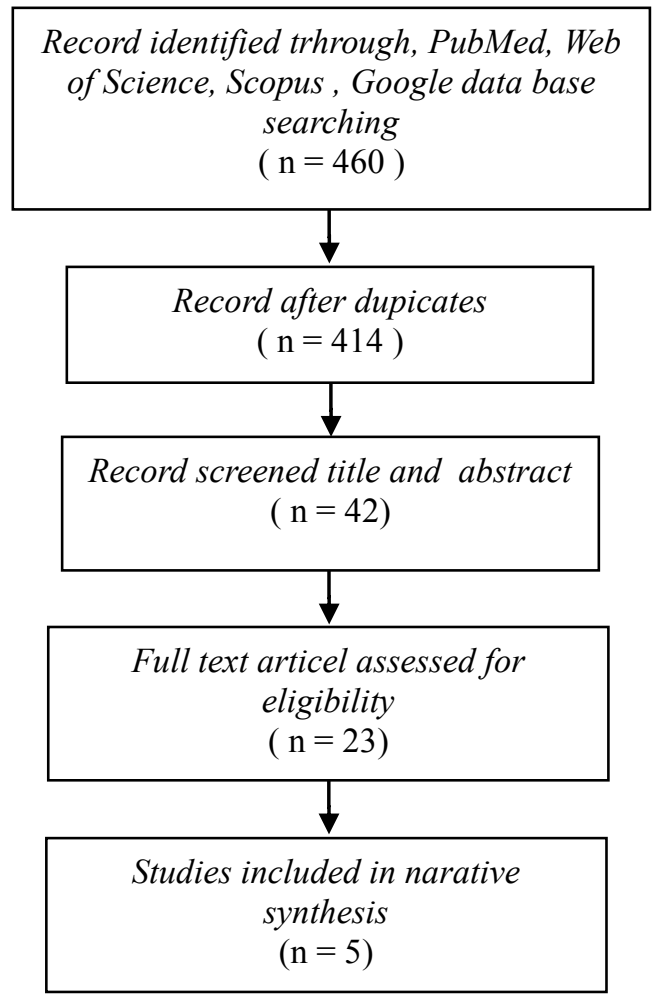

Gambar 1. Diagram Alir Studi Pencarian dan Seleksi Artikel

\section{Hasil}

Lierature review ini disusun berdasarkan pada kajian artikel terseleksi yang mengacu pada tujuan penelitian ini. Setelah memasukan kata kunci kunci community dengue control, engangment dengue control, sosial capital dengue control penulis memperoleh 42 artikel yang relevan dengan topik untuk diambil. Namun setelah disaring sesuai dengan kriteria inklusi diperoleh 23 artikel. Sesuai dengan inklusi penelitian ini untuk mengetahui keterlibatan sosial dalam pengendalian vektor maka diperoleh 5 artikel. Literatur review ini disintesis mengunakan metode narasi dengan mengelompokan data hasil ekstraksi serupa dengan hasil yang diukur untuk menjawab tujuan penelitian. Hasil artikel penelitian yang sesuai dengan kriteria inklusi di gabungkan dalam tabel yang meliputi nama peneliti, judul penelitian, intervensi, hasil penelitian dan kesimpulan yang disajikan dalam tabel 1 .

\section{Pembahasan}

Berdasarkan tabel 1 dari 5 artikel yang dirangkum, secara keseluruhan semua artikel menyatakan hal yang sama yaitu ada hubungan antara peran serta masyarakat terhadap penurunan indikator penularan demam berdarah. Meskipun secara umum artikel tersebut membahas peranan masyarakat dalam pemberantasan penyakit DBD. Variabel independen yang dibahas adalah faktor entomologi, pengetahuan, sikap, dan perilaku. Penelitian ini memiliki keterbatasan artikel pada sumber data base yang ditemukan berkaitan dengan pelibatan masyarakat dalam upaya pengendalian DBD di Indonesia.

\section{Pengetahuan, Sikap dan Praktik}

Gambaran pengetahuan, sikap dan praktik mengenai pengendalian DBD di masyarakat di ungkap salah satunya diungkap oleh Harapan, et al pada studi di Aceh yang menemukan lebih dari 50\% peserta memiliki pengetahuan yang buruk tentang Dengue Fever (DF). Faktor yang terkait dengan pengetahuan yang baik mengenai DBD adalah tingkat pendidikan yang lebih tinggi, pekerjaan (PNS, pegawai 

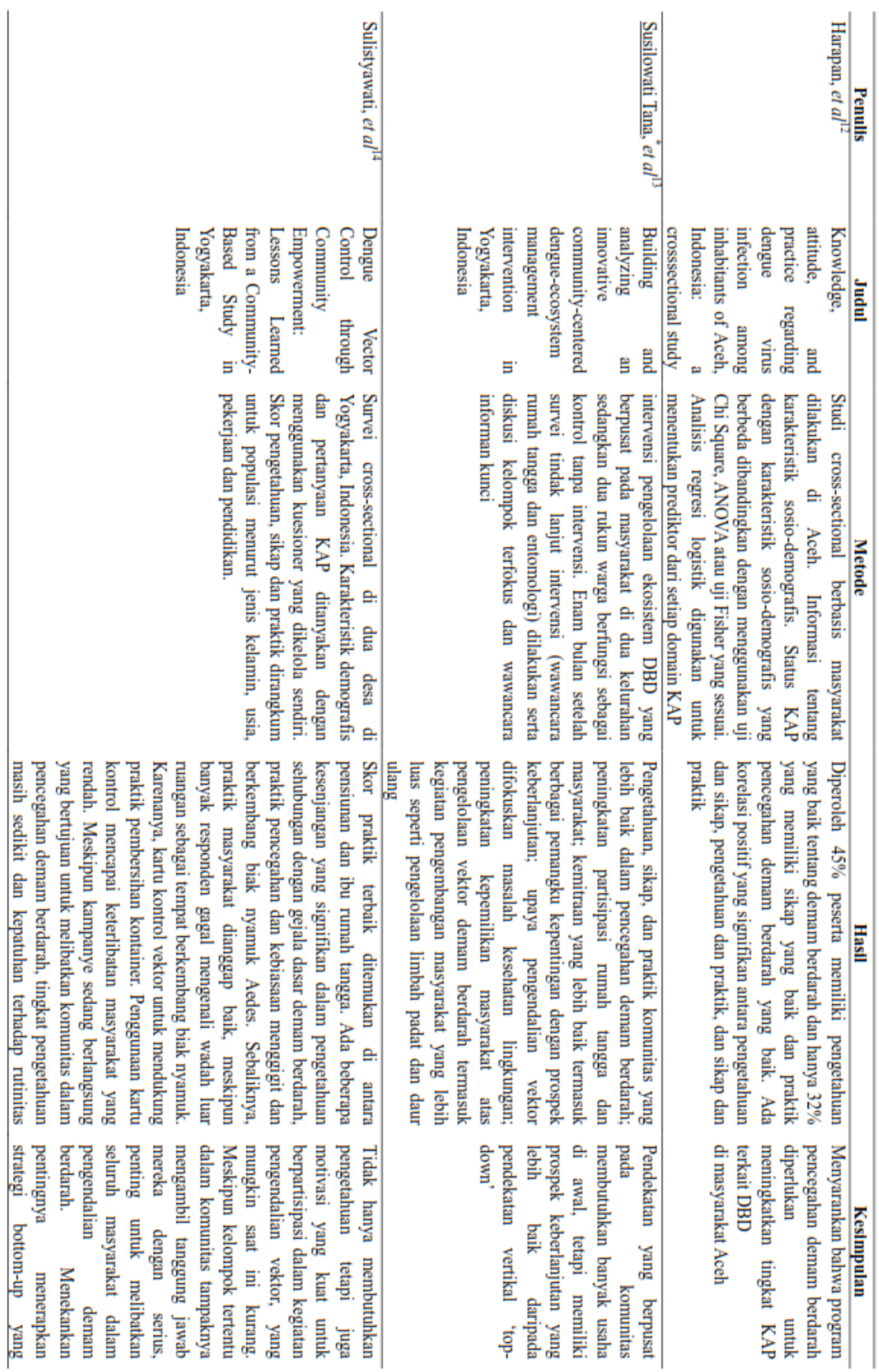

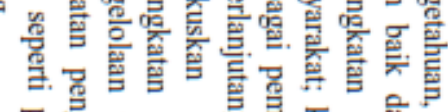

茄哭布

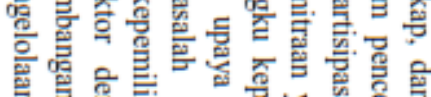

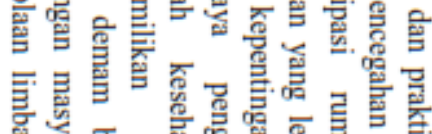

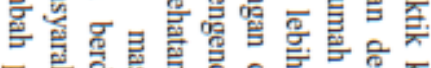

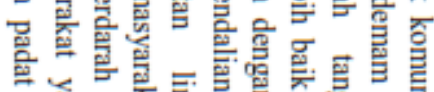

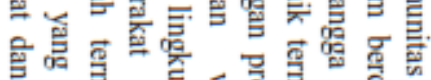

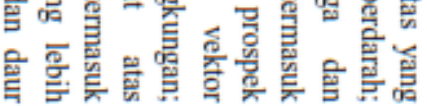

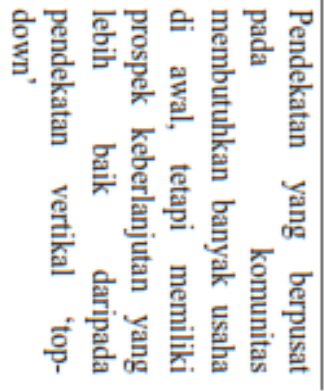

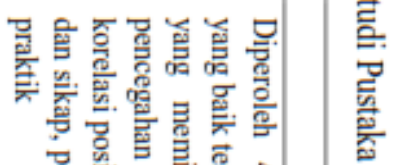

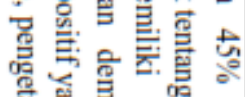

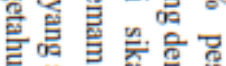

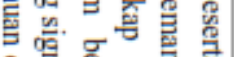

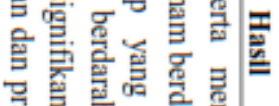

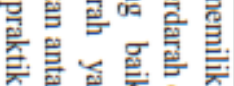

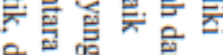

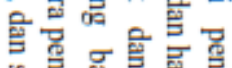

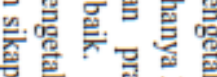

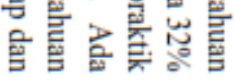

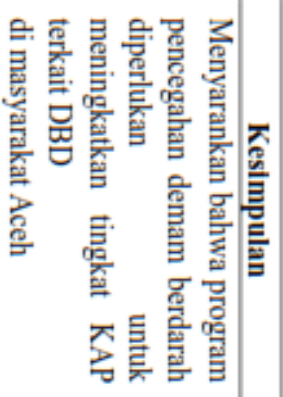




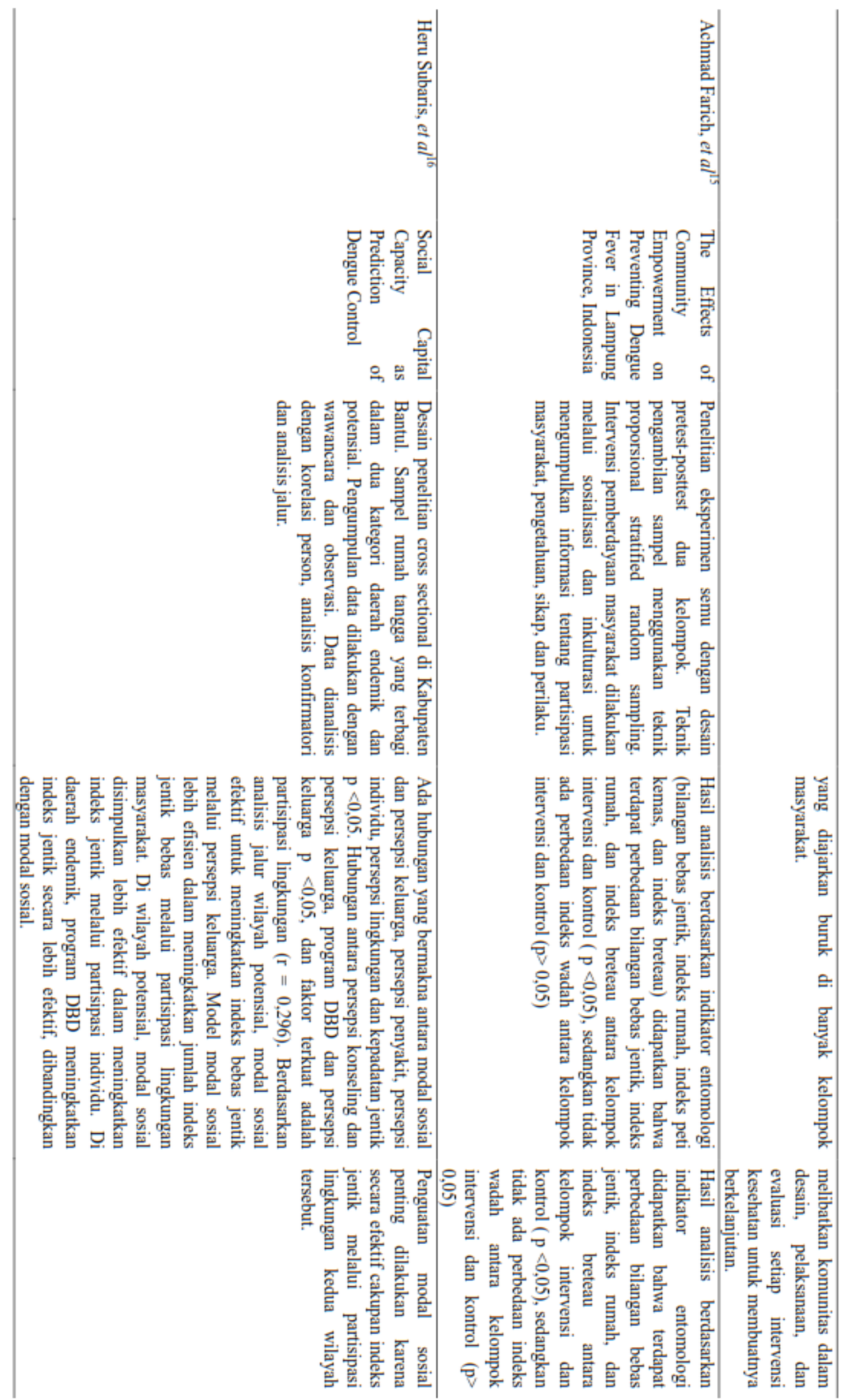


swasta, pengusaha, pelajar), status belum menikah, pendapatan keluarga bulanan tinggi, Sosial Ekonomi tinggi, dan tinggal di kota. Ada hubungan yang kuat antara pendidikan formal dan pengetahuan tentang DF dalam penelitian ini. Penelitian tersebut juga menemukan hubungan yang lemah antara pengetahuan DBD dan praktik pencegahan. Meskipun lebih dari 45\% peserta memiliki pengetahuan yang baik tentang DF (berdasarkan poin batas $80 \%$ ), hanya $32 \%$ yang memiliki praktik pencegahan yang baik. ${ }^{12}$ Penelitian lain oleh Rakhmani AN, et al juga menunjukkan bahwa persepsi positif merupakan komponen kunci yang mempengaruhi praktik pencegahan, terutama persepsi terhadap manfaat dan hambatan perilaku pencegahan. ${ }^{17}$

Pengetahuan dan sikap dikaitkan dengan perilaku, dan keduanya lebih mudah diperbaiki daripada meningkatkan faktor-faktor lain yang terkait dengan perilaku yang baik, seperti status ekonomi. Selain itu, kebiasaan negatif yang sudah mendarah daging sulit dihilangkan dengan berbagi pengetahuan sederhana. Mungkin pendekatan yang lebih personal dan praktis dalam program pendidikan kesehatan diperlukan untuk mempengaruhi perubahan perilaku. ${ }^{18}$ Meskipun para peserta memiliki pengetahuan dasar mengenai vektor dan gejala penularan DBD dan umumnya menyadari keseriusan penyakit dan mempraktikkan beberapa tingkat pencegahan, masih banyak yang harus dilakukan untuk meningkatkan kapasitas masyarakat dalam memerangi demam berdarah. Kesenjangan dalam pengetahuan pencegahan, sikap terhadap risiko tertular, dan praktik pemusnahan sumber nyamuk, untuk beberapa nama, dapat diatasi melalui upaya pendidikan lebih lanjut. ${ }^{19}$ Sejalan dengan studi lain oleh Alyousefi TAA, et al bahwa pengetahuan yang buruk tentang DF memiliki hubungan positif yang signifikan dengan praktik pencegahan yang buruk. ${ }^{20}$ Meningkatkan kesadaran dan sikap yang baik serta dorongan positif dari praktik baik selanjutnya adalah penting. Melihat hasil (misalnya pengurangan populasi nyamuk Aedes atau kasus demam berdarah) dari perilaku pencegahan mereka dapat memicu motivasi berkelanjutan untuk melakukan aktivitas.

\section{Intervensi gotong royong}

Penelitian di Kota Yogyakarta oleh Susilowati Tana, et al diperoleh hasil yang menunjukan bahwa intervensi keterlibatan bersama masyarakat melalui gotong-royong mampu memberikan efek terhadap keberadaan jentik di rumah. Intervensi penelitian ini berupa keterlibatan dan pemberdayaan masyarakat melalui pertemuan, forum, tokoh masyarakat (kader), rukun tetangga, paguyuban perempuan, sekolah dasar. Partisipasi aktif masyarakat difasilitasi melalui forum komunitas. Forum komunitas adalah forum di tingkat lingkungan. Peningkatan indikasi berberhasil metode ini adalah masyarkat secara aktif pada tahap perencanaan dan pengelolaan. Kemudian, anggota komunitas memimpin, menentukan prioritas dan mengelola program. Masyarakat belajar keterampilan untuk pemantauan dan evaluasi. Perempuan secara aktif terutama melalui kelompok seperti dasawisma atau PKK. Wanita dan pria bersama-sama membuat keputusan. Pengembangan program untuk mencapai kemandirian finansial dan menguasai desain program Anggota masyarakat bekerja untuk memobilisasi sumber daya lokal untuk menggantikan pendanaan eksternal dengan sumber daya mereka sendiri. Anggota komunitas merancang program dengan saran teknis sesuai kebutuhan. Pengambilan keputusan melibatkan perempuan. Evaluasi partisipatif dilakukan masyarakat dengan menggunakan indikator lokal yang disepakati. Komunitas tersebut aktif terlibat dalam pemantauan dan memutuskan bagaimana menanggapi temuan. ${ }^{13}$

\section{Social Capital}

Dari hasil penelitian di Bantul, Yogyakarta oleh Subaris, et al diperoleh hasil yang menunjukan bahwa partisipasi 
lingkungan pada daerah endemis lebih rendah dibandingkan dengan daerah potensial. Partisipasi lingkungan memiliki peran yang sangat mendasar untuk memutus mode penularan vektor demam berdarah. Partisipasi lingkungan membantu berbagai program pemerintahan yang terkait dengan pengendalian demam berdarah. Program pemerintah tanpa dukungan partisipasi masyarakat cenderung tidak ada artinya karena masyarakat tidak terlibat dalam pemberantasan penyakit tersebut, sehingga program yang ada cenderung tidak berjalan dengan baik. Program pengendalian demam berdarah akan berkelanjutan jika keterlibatan masyarakat memiliki peran di dalam program. Program pengendalian demam berdarah juga bisa lebih berkelanjutan jika masyarakatnya terlibat langsung dengan perilaku mereka. Situasi ini membutuhkan pendekatan komunitas diperlakukan sebagai subjek dan objek. Pendekatan komunitas dapat dilakukan melalui peran komunitas pemimpin, pemuka agama, atau lembaga yang berada dalam lingkup masyarakat. ${ }^{16}$

Keterlibatan tokoh masyarakat dalam mendorong warga memiliki efek yang luas pada setiap komponen masyarakat. Orang-orang menjadi terbiasa menggunakan modal sosial yang ada dalam bentuk jaringan, norma, dan kepercayaan bahwa perubahan akan terjadi. ${ }^{21}$ Strategi penggerakan pemimpin daerah lintas sector, bukan hanya tenaga kesehatan, untuk tetap bekerja bahu membahu dengan komunitas mendemonstrasikan pengendalian demam berdarah. Modal sosial dapat bekerja untuk memberi pengaruh atau dampak positif. Elemen asosiasi sosial, seperti kepercayaan, norma, dan jaringan, dapat meningkatkan kemampuan masyarakat dengan mendorong kegiatan terstruktur. Potensi modal sosial untuk mengatasinya masalah. Modal sosial adalah sumber daya dimiliki oleh masyarakat dalam bentuk norma atau nilai-nilai yang memfasilitasi dan membangun kerjasama melalui jaringan yang harmonis dan kondusif, interaksi dan komunikasi. Ini sangat penting bagi gagasan modal sosial.

\section{Partisipasi masyarakat}

Studi oleh Achmad Farich, et al di Provinsi Lampung mencoba untuk memberikan pemahaman tentang pengetahuan, sikap, dan praktik saat ini. Berkenaan dengan DBD dan pencegahan DBD sebagai landasan untuk perbaikan partisipasi masyarakat dalam pengendalian DBD di Kota Yogyakarta. Penelitian ini menilai pengetahuan, sikap orang dan praktik terkait demam berdarah dan pengendalian demam berdarah menggunakan apa yang disebut kuesioner KAP. Berdasarkan hasil studi baseline ini dilakukan intervensi dengan desain pre-post control. Intervensi dilaksanakan untuk lebih mengeksplorasi praktek pengendalian vektor orang dan untuk lebih memahami apakah pemantauan rutin praktik pembersihan kontainer di tingkat rumah tangga akan mengarah hingga penurunan indeks larva lokal. Singkatnya, tampaknya ada kesenjangan yang signifikan dalam populasi penelitian tentang gejala dasar demam berdarah, praktik pencegahan, serta kebiasaan menggigit dan berkembang biak nyamuk Aedes, terutama yang berhubungan dengan tempat berkembang biak di luar ruangan. Skor pengetahuan keseluruhan dalam populasi penelitian paling baik sedang (rata-rata $=3,7, \quad \mathrm{SD}=1,6$ ). Sebaliknya, skor sikap dan latihan dianggap baik atau sangat baik (mean $=25.5, \mathrm{SD}=4.0$ dan mean $=9.2, \mathrm{SD}=1.3$ ). Sebagian besar responden menunjukkan sikap dan praktik yang tepat yang berkaitan dengan pengendalian vektor secara umum dan pembersihan dalam ruangan pada khususnya. Kelemahan penting ditemukan dalam hal pemahaman masyarakat tentang kebiasaan menggigit nyamuk dan pentingnya memperhatikan juga habitat perkembangbiakan di luar ruangan. Meskipun demikian, populasi penelitian tampaknya mengakui peran mereka sendiri dalam pencegahan demam berdarah. ${ }^{14}$ Strategi promosi kesehatan mencakup partisipasi masyarakat. Partisipasi adalah 
keterlibatan masyarakat secara sukarela dalam perubahan yang ditentukan sendiri, yang juga dapat berarti keterlibatan masyarakat dalam pengembangan diri, kehidupan, dan lingkungan. ${ }^{22}$

\section{Pemberdayaan Masyarakat}

Hasil penelitian menunjukkan bahwa terdapat perbedaan median skor pengetahuan, sikap, dan perilaku antara kelompok intervensi dan kelompok kontrol. Hasil analisis berdasarkan indikator entomologi (bilangan bebas jentik, indek rumah, indeks peti kemas, dan indeks breteau) didapatkan bahwa terdapat perbedaan bilangan bebas jentik, indek rumah, dan indeks breteau antara kelompok intervensi dan kelompok kontrol. Sedangkan container index tidak terdapat perbedaan antara kelompok intervensi dan kelompok kontrol. ${ }^{15}$ Pemberdayaan masyarakat dalam pengendalian DBD dapat dilakukan dengan berbagai cara yang disesuaikan dengan kondisi masyarakat. Masyarakat diajak bersama untuk mengidentifikasi permasalahan terkait DBD, menentukan program yang dapat dilaksanakan, melaksanakan program pemantauan, dan mengevaluasi pelaksanaan pengendalian DBD. $^{23}$

\section{Kesimpulan}

Pengendalian DBD sampai saat ini masih belum dapat terselesaikan. Berbagai upaya baik pemerintah maupun masyarakat untuk melakukan pengendalian penyakit DBD. Namun upaya pelibatan masyarakat menjadi penting dalam upaya pengendalian DBD. Pelibatan masyarakat berupa peningkatan pengetahuan, sikap, perilaku, modal sosial dan pemberdayaan masyarakat memiliki andil yang kuat terhadap keberhasilan dalam pengendalian DBD. Literature review ini dapat memberikan rekomendasi mengenai peningkatan peran masyarakat dalam setiap program pengendalian DBD di Indonesia. Hasil kajian sistematik ini hanya mencakup wilayah Indonesia, oleh karena itu penelitian lebih lanjut diharapkan dapat meningkatkan cakupan di berbagai negara atau regional.

\section{Daftar Pustaka}

1. Messina JP, Brady OJ, Golding N, Kraemer MUG, Wint GRW, Ray SE, et al. The current and future global distribution and population at risk of dengue. Nat Microbiol [Internet]. 2019 Sep 1 [cited 2020 Dec 11];4(9):1508-15. Available from: /pmc/articles/PMC6784886/?report=abstract

2. Simmons CP, Farrar JJ, van Vinh Chau N, Wills B. Dengue. N Engl J Med [Internet]. 2012 Apr 12 [cited 2020 Dec 11];366(15):1423-32. Available

from: http://www.nejm.org/doi/abs/10.1056/NEJMra1 110265

3. Bhatt S, Gething PW, Brady OJ, Messina JP, Farlow AW, Moyes CL, et al. The global distribution and burden of dengue. Nature [Internet]. 2013 Apr 25 [cited 2020 Dec 11];496(7446):504-7. Available from: /pmc/articles/PMC3651993/?report=abstract

4. Shepard DS, Undurraga EA, Halasa YA, Stanaway JD. The global economic burden of dengue: a systematic analysis. Lancet Infect Dis [Internet]. 2016 Aug 1 [cited 2021 May 22];16(8):935-41. Available from: http://www.thelancet.com/article/S1473309916 001468/fulltext

5. Brady OJ, Gething PW, Bhatt S, Messina JP, Brownstein JS, Hoen AG, et al. Refining the Global Spatial Limits of Dengue Virus Transmission by Evidence-Based Consensus. Reithinger R, editor. PLoS Negl Trop Dis [Internet]. 2012 Aug 7 [cited 2020 Dec 11];6(8):e1760. Available from: https://dx.plos.org/10.1371/journal.pntd.00017 60

6. Kementerian Kesehatan RI. Profil Kesehatan Indonesia Tahun 2019 [Internet]. Jakarta; 2020 [cited 2020 Dec 11]. Available from: https://pusdatin.kemkes.go.id/resources/downlo ad/pusdatin/profil-kesehatan-indonesia/ProfilKesehatan-Indonesia-2019.pdf

7. Setiati TE, Wagenaar JFP, De Kruif MD, Mairuhu ATA, Van Gorp ECM, Soemantri A. Changing Epidemiology of Dengue Haemorrhagic Fever in Indonesia. Vol. 30, Dengue Bulletin. 2006.

8. Karyanti MR, Uiterwaal CSPM, Kusriastuti R, Hadinegoro SR, Rovers MM, Heesterbeek H, et al. The changing incidence of Dengue Haemorrhagic Fever in Indonesia: A 45-year registry-based analysis. BMC Infect Dis [Internet]. 2014 Jun 24 [cited 2020 Dec 11];14(1). Available from: https://pubmed.ncbi.nlm.nih.gov/25064368/

9. Trapsilowati W, Pujiyanti Balai Besar Penelitian dan Pengembangan Vektor dan Reservoir Penyakit Jl Hasanudin No A, Tengah J. 
Implementasi Peraturan Daerah Tentang Pengendalian Demam Berdarah Dengue Di Kota Semarang Implementation Of Local Government Regulation On Dengue Control In Semarang City. Vektora J Vektor dan Reserv Penyakit [Internet]. 2018 Oct 31 [cited 2020 Dec 14];10(2):119-24. Available from: https://ejournal2.litbang.kemkes.go.id/index.ph $\mathrm{p} / \mathrm{vk} /$ article/view/1052

10. Andersson N, Nava-Aguilera E, Arosteguí J, Morales-Perez A, Suazo-Laguna H, Legorreta-Soberanis J, et al. Evidence based community mobilization for dengue prevention in Nicaragua and Mexico (Camino Verde, the Green Way): Cluster randomized controlled trial. BMJ [Internet]. 2015 Jul 8 [cited 2020 Dec 11];351. Available from: http://dx.doi.

11. Liberati A, Altman DG, Tetzlaff J, Mulrow C, Gøtzsche PC, Ioannidis JPA, et al. The PRISMA statement for reporting systematic reviews and meta-analyses of studies that evaluate healthcare interventions: explanation and elaboration. BMJ [Internet]. 2009 Jul 21 [cited 2020 Nov 15];339. Available from: http://www.bmj.com/

12. Harapan H, Rajamoorthy $\mathrm{Y}$, Anwar S, Bustamam A, Radiansyah A, Angraini P, et al. Knowledge, attitude, and practice regarding dengue virus infection among inhabitants of Aceh, Indonesia: A cross-sectional study. BMC Infect Dis [Internet]. 2018 Feb 27 [cited 2020 Dec 14];18(1). Available from: https://pubmed.ncbi.nlm.nih.gov/29486714/

13. Tana S. Building and analyzing an innovative community-centered dengue-ecosystem management intervention in Yogyakarta, Indonesia. Pathog Glob Health [Internet]. 2013 [cited 2020 Dec 14];106(8):469-78. Available from:

https://pubmed.ncbi.nlm.nih.gov/23318239/

14. Sulistyawati S, Astuti FD, Umniyati SR, Satoto TBT, Lazuardi L, Nilsson M, et al. Dengue vector control through community empowerment: Lessons learned from a community-based study in Yogyakarta, Indonesia. Int J Environ Res Public Health [Internet]. 2019 Mar 2 [cited 2020 Dec 14];16(6). Available from: https://pubmed.ncbi.nlm.nih.gov/30897770/

15. Farich A, Lipoeto NI, Bachtiar H, Hardisman H.
The effects of community empowerment on preventing dengufever in Lampung Province, Indonesia. Open Access Maced J Med Sci [Internet]. 2020 Apr 8 [cited 2020 Dec 14];8(E):194-7. Available from: https://doi.org/10.3889/oamjms.2020.4192

16. Subaris H, Subiyanto S, Tri Kartono D, Lestary E. Social Capital Capacity as Prediction of Dengue Control. Int J Public Heal Sci [Internet]. 2016 Mar 1 [cited 2020 Dec 15];5(1):111. Available from: http://ijphs.iaescore.com/index.php/IJPHS/artic le/view/4772

17. Rakhmani AN, Limpanont Y, Kaewkungwal J, Okanurak K. Factors associated with dengue prevention behaviour in Lowokwaru, Malang, Indonesia: A cross-sectional study. BMC Public Health. 2018;18(1).

18. Selvarajoo S, Liew JWK, Tan W, Lim XY, Refai WF, Zaki RA, et al. Knowledge, attitude and practice on dengue prevention and dengue seroprevalence in a dengue hotspot in Malaysia: A cross-sectional study. Sci Rep. 2020;10(1).

19. Nguyen H Van, Than PQT, Nguyen TH, Vu GT, Hoang CL, Tran TT, et al. Knowledge, attitude and practice about dengue fever among patients experiencing the 2017 outbreak in vietnam. Int $\mathbf{J}$ Environ Res Public Health. 2019;16(6).

20. Alyousefi TAA, Abdul-Ghani R, Mahdy MAK, Al-Eryani SMA, Al-Mekhlafi AM, Raja YA, et al. A household-based survey of knowledge, attitudes and practices towards dengue fever among local urban communities in Taiz Governorate, Yemen. BMC Infect Dis. 2016;16(1).

21. Asri, Nuntaboot $K$, Festi Wiliyanarti P. Community social capital on fighting dengue fever in suburban Surabaya, Indonesia: A qualitative study. Int J Nurs Sci. 2017;4(4).

22. Koenraadt CJM, Tuiten W, Sithiprasasna R, Kijchalao U, Jones JW, Scott TW. Dengue knowledge and practices and their impact on Aedes aegypti populations in Kamphaeng Phet, Thailand. Am J Trop Med Hyg. 2006;74(4).

23. Sukesi TY, Supriyati S, Satoto TT. Pemberdayaan Masyarakat Dalam Pengendalian Demam Berdarah Dengue (Literature Review). J Vektor Penyakit. 2018;12(2). 